\title{
Executing Product Broadening Procedures for the Sustainability of an Innovation Organization - A Contextual Analysis of Microsoft Corporation
}

\author{
Vinayachandra $^{1} \& 2$ \& Krishna Prasad $\mathrm{K}^{3}$ \\ ${ }^{1}$ Research Scholar, College of Computer Science and Information Science, Srinivas \\ University, Mangalore, India \\ ${ }^{2}$ Assistant Professor, St Philomena College, Puttur, India \\ ${ }^{3}$ College of Computer Science and Information Science, Srinivas University, Mangalore, \\ India \\ E-mail: veeciashu@gmail.com
}

Type of the Paper: Explorative Research.

Type of Review: Peer Reviewed.

Indexed In: OpenAIRE.

DOI: http://doi.org/10.5281/zenodo.3510312.

Google Scholar Citation: IJCSBE

\section{How to Cite this Paper:}

Vinayachandra, \& Krishna Prasad, K. (2019). Executing Product Broadening Procedures for the Sustainability of an Innovation Organization - A Contextual Analysis of Microsoft Corporation. International Journal of Case Studies in Business, IT, and Education (IJCSBE), 3(2), 28-40. DOI: http://doi.org/10.5281/zenodo.3510312.

International Journal of Case Studies in Business, IT and Education (IJCSBE)

A Refereed International Journal of Srinivas University, India.

IFSIJ Journal Impact Factor for 2019-20 $=4.252$

(C) With Authors.

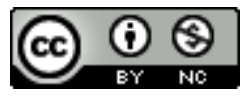

This work is licensed under a Creative Commons Attribution-Non Commercial 4.0 International License subject to proper citation to the publication source of the work.

Disclaimer: The scholarly papers as reviewed and published by the Srinivas Publications (S.P.), India are the views and opinions of their respective authors and are not the views or opinions of the S.P. The S.P. disclaims of any harm or loss caused due to the published content to any party. 


\title{
Executing Product Broadening Procedures for the Sustainability of an Innovation Organization - A Contextual Analysis of Microsoft Corporation
}

\author{
Vinayachandra $^{1 \text { \& } 2}$ \& Krishna Prasad $\mathbf{K}^{3}$ \\ ${ }^{1}$ Research Scholar, College of Computer Science and Information Science, Srinivas \\ University, Mangalore, India \\ ${ }^{2}$ Assistant Professor, St Philomena College, Puttur, India \\ ${ }^{3}$ College of Computer Science and Information Science, Srinivas University, Mangalore, \\ India \\ E-mail: veeciashu@gmail.com
}

\begin{abstract}
Started in 1975, with a view to develop and vend BASIC interpreter, today, Microsoft develop, produce, license, support and sell worldwide software, user-level electronics, personal computers, and allied services. The company is world-famous because of its best software products Windows operating systems, Office suits, IE and Edge. The company's notable hardware pieces are Xbox and Microsoft Surface family touch-screen computers. The company is listed as the top software company by Forbes Global for many years. From its inception to date, the company is maintaining top ranking technology-wise, product-wise, service-wise, revenue-wise, and growth-wise. It is possible for the company to sustain growth because of the integration and implementation of product diversification strategy. Over the years the company transformed from just a developer and seller of interpreter to producer \& marketer of wide variety of software-hardware products. This paper analyses the strategies the company adopted and incorporated in diversifying product and services lineup to sustain growth and maintain market stability. It also analyses the relevance and acceptability of different Microsoft products, its customer base, and software market share and near future strategies.
\end{abstract}

Keywords: Microsoft, strategies, product diversification, Windows, generic, intensive.

\section{INTRODUCTION :}

Microsoft is Redmond based American company founded in the year 1975. It develops and supports computer software, IT services, PC hardware and solutions, which afford customers with a special value and help individual users and corporate customers, realize their potential. The company proffers a variety of services and business solutions together with cloud to customers and business. Microsoft presents software, services, platform and content to customers and support \& consultation to enterprises. It includes operating systems, productivity/server/business solution applications, system management tools, application development tools, games, support to cloud, IoT, cyber security and design, manufacture \& trade devices such as PCs, tablets, gaming \& entertainment consoles, intelligent devices and connected accessories. Its business platforms and software tools enable small business to drive productivity, large business to build competitive advantage, and public-sector to compel efficiency [1-3]. This case study of Microsoft contains 1) Background, 2) Mission \& Vision 3) Company’s Progress, 4) Growth Strategies, 5) Finance \& Human Resource details, 6) Marketing Strategy, 7) Major Acquisitions, 8) Major Cutbacks, 9)Organizational Structure, 10) SWOC analysis, 11) Major Competitors, 12) Stakeholders and 13) Conclusion. 


\section{BACKGROUND :}

From a mere developer and seller of the BASIC interpreter for the Altair 8800 systems to produce operating systems, application of different types, system management tools, software development tools, support to emerging technologies and design, manufacture \& trade devices, the company has been recording steady growth and maintaining top rankings in the global software company rankings. The company is considered as one-of-kind top-notch tech-enterprises in the sphere [2].

The brand Microsoft and its products are ubiquitous today. One may think, what made Microsoft so much famous, relevant and versatile? It is because of the implementation of its own strategies, which placed Microsoft in competitive advantage compared to other technology enterprises. This paper analyses the strategies the company incorporated in diversifying product and services lineup to sustain growth and maintain market stability. It also analyses the relevance and influence of different Microsoft products, its customer base, and software market share and near-future plans by considering and extracting secondary data available in various sources such as published articles and online resources. For the purpose of statistics, the US version of the Official Website of the Microsoft Corp. was considered as the primary source. To perform analysis and put it in structured order [4-6] methods highlighted in different works were referred.

\section{MISSION \& VISION :}

The company's corporate vision is "to help people and businesses throughout the world realize their full potential" and corporate mission be "to empower every person and every organization on the planet to achieve more" [7].

Microsoft's mission and vision are in sync with its business. The company's multifaceted growth and story of success is just a mirror for its commitment to fulfill and fall in line with stated statements. The statement of vision guarantees the business development targeted to meet anticipated future condition. It indicates in what way the company can help individual and corporate customers. Concurrently, the corporate mission statement points out the strategies adopted to grow the business in line with stated vision and reach it. The mission indicates how company aims to empower its stated customers. Moreover, the strongly aligned vision \& mission statements of the Microsoft streamlines the strategies the company necessarily to adopt with a view to address competitions from rivals.

\section{THE PROGRESS :}

Bill Gates and Paul Allen established "Micro-soft" on April 4, 1975 in Albuquerque at New Mexico, encouraged as a result of a strong contract they just signed with MITS to market and distribute their translator as ' Altair Basic. With Bill Gates as its CEO, the company recorded $\$ 16,000$ income in total in the year with 3 employees on the roll.

Microsoft was registered in 1976. It developed FORTRAN, COBOL and Assembler, in tune with expanding the PC's capacities in the fields of science and business. In 1978, Microsoft's first offshore office was opened in Japan. The company transferred its operations to Bellevue in Washington in 1979. With the addition of a fresh Belgian representative, Vector Microsoft, the company is expanding its service to the Europe. By the time, Microsoft has already under agreement with several OEMs. In 1980, Microsoft introduced Z-80 SoftCard, the company's first hardware product, which facilitated to execute programs originated for the CP/M OS on the Apple II computers with very minimum modifications. The year saw entry of Microsoft into the OS business with Xenix. Same year Microsoft introduced Pascal language. However, MS-DOS, the flagship product of the company of the time, consolidated the dominance of the company in the operating system market.

The major break of the company was in 1981 when IBM entered into a partnership to produce and supply crucial operating system, MS-DOS 1.0 to IBM PCs. Microsoft reorganized into a private company in the same year. Gates and Allen took over the responsibility as President \& Chairman and Executive Vice President respectively. The company incorporated into Microsoft Inc. The enhanced version of BASIC, GW-BASIC was released in 1983. In the same year the company introduced programming language Microsoft C. The company's first application software Microsoft Multiplan 
spreadsheet was introduced. Microsoft unveiled Microsoft Windows that provided a graphical operating environment. With the release of Microsoft Mouse the company

expanded into different markets. Microsoft Press, the company's own publishing division was started.

Microsoft's decennial celebrations are marked with the launching of Microsoft Windows 1.0 in 1985. The company launched Microsoft Works in 1986. In the same year, Microsoft shifted its headquarters to Redmond in Washington. The company's stock goes public. In 1987, corporation introduced OS/2 produced with IBM to OEMs. Microsoft brought into its ambit Forethought, Inc and made it as its Graphics Business Unit. It announced the shipment Microsoft Bookshelf, a CD-ROM application containing 10 most popular and helpful creations in a single disk. Microsoft also announced Microsoft Excel for Windows and LAN Manager. The company announced Microsoft SQL Server in 1988.

Microsoft moves to Canyon Park, Bothell's new manufacturing and distribution location. The Office Suite was released in 1989 bundled with separate productivity applications. Microsoft launched Windows 3.0 in 1990 and Windows 3.1 in 1992. Microsoft announced Access for Windows in 1992. This relational DBMS offers simple, transparent data access; strong, usability-tested instruments; and a solid environment for development. Windows NT, a client-server solution with a strong, consistent and open platform was unveiled in 1993. In the same year the company introduced 'Creative Writer and Fine Artist', its first ever produce designed exclusively for children. Encarta, the first electronic encyclopedia was made available to the customers in 1994. Microsoft took over SOFTIMAGE Inc. Well known company tag line "Where Do You Want To Go Today" released.

Windows 95 and MSN was made available on its $2^{\text {nd }}$ decennial birth year, 1995, Microsoft Bob for Windows, a social interface, with all new user-interface and eight core features (E-Mail, Address Book, Calendar, Letter Writer, Checkbook, Household Manager, Financial Guide, and GeoSafari) was announced. SideWinder 3D Pro was also announced. In 1996, the company announced ActiveX Technologies. SQL Server 6.5 and Flight Simulator for Win95 were also emancipated. In 1997 Microsoft made available the Office 97 worldwide and acquired Interse Corp. IE 4.0 was released. The year 1998 is most memorable for the company as it made available one of its best sold products Windows 98 worldwide. In the same year the company launched its India Development Center in Hyderabad.

Microsoft's commitment to build innovative products for Macintosh continues as it published Office 98 for Macintosh, a variety of Office Suite to Mac customers. Exchange Server made remarkable progress as it outsold Lotus Notes in 1998. In 1999, Microsoft launched Encarta Africana. Microsoft unveiled its first online store, Shop. IE5.0 and Office 2000 were launched. Microsoft acquired Visio Corporation in 2000. Bill Gates assumed a fresh position for himself as Chairman \& Chief Software Architect and Steve Ballmer became President \& CEO. Microsoft launched Windows 2000.

Microsoft Windows XP, MS Office XP and Xbox made available in 2001. In 2002, Microsoft Visual Studio.NET launched incorporating. Tablet PC was launched. In the same year company released Windows Server 2003, announced Windows Mobile \& Microsoft Office System. Microsoft unveiled Windows XP Media Center Edition 2005 in 2004. The company launched Xbox 360 in 2005. Windows Vista was released in 2007. In 2008, the company introduced Windows Server 2008, SQL Server 2008 and Visual Studio 2008. Windows 7 was published in 2009. Same year Bing decision engine was also launched. In the same year the company opened its first physical store in Scottsdale, Arizona. In 2010, Microsoft launched Office 2010, Windows Phone 7 and Microsoft Lync. Microsoft launched Office 365 in 2011. It formalized the acquisition of Luxembourg-based Skype in the same year.

Come year 2012, Yammer was obtained by Microsoft. It released Windows 8, Windows Server 2012, Visual Studio 2012, and Microsoft Surface. Microsoft launched Office 2013 and expands Office 365 in 2013. Office for iPad was floated in 2014 and also announced the availability of Office apps for Android tablets. It acquired of Nokia with a nomenclature Mobile Qy in the same year. Also it acquired Mojang, the video game development company. Satya Nadella became the CEO. Microsoft's Windows 10, Surface 3 and Office 2016 released in the year 2015. SQL Server 2016, and Dynamics 365 launched in the year 2016. Microsoft acquired LinkedIn in the same year. The first HoloLens headset introduced with blended reality technology. It introduced Visual Studio 2017 
and Xbox One X in 2017. Opening of campus in Dublin, Ireland, announcement of Surface Hub 2, unveiling of Xbox C, made available of Surface Go, release of PowerShell Core 6.0 for the macOS and Linux are the highlights of 2018. Company completed the acquisition of GitHub [8-9].

\section{GROWTH STRATEGIES :}

Microsoft Corporation has adopted two classes of strategies - generic and intensive growth strategies [10] to keep company at competitive advantage in the PC software and hardware business. As shown in below Fig. 1, its generic approach directly intensive approach. This arrangement optimizes companies overall performance. Generally, the generic strategy of a company shows the overall approach to ensuring company competitiveness and intensive growth strategies outline the methods used to guarantee company growth \& development [11].

\begin{tabular}{|c|c|c|c|}
\hline \multicolumn{4}{|c|}{$\begin{array}{c}\text { Generic Strategy } \\
\text { (Competitive advantage) }\end{array}$} \\
\hline \multicolumn{4}{|c|}{$\begin{array}{l}\text { Intensive Strategies } \\
\quad \text { (Intensive growth) }\end{array}$} \\
\hline $\begin{array}{l}\text { Market Penetration } \\
\text { (Primary Strategy) }\end{array}$ & $\begin{array}{c}\text { Product } \\
\text { Development } \\
\text { (Secondary Strategy) }\end{array}$ & $\begin{array}{c}\text { Market } \\
\text { Development } \\
\text { (Supporting Strategy) }\end{array}$ & $\begin{array}{c}\text { Diversification } \\
\text { (Supporting Strategy) }\end{array}$ \\
\hline
\end{tabular}

Fig.1: Microsoft's generic and intensive strategies alignment

\section{Generic Strategy}

To keep company in competitive advantage over to its rivals, the company uses 'Broad Differentiation' as its competitive advantage strategy. This implies that distinctive software-hardware products targeted to a broad chunk of customers. The company doesn't keep any stone unturned to make its products distinctive in terms of varied characteristics. Through this approach the company expands its market, reaches wide range of customers and establishes its competitive benefit [12].

\section{Intensive Strategies}

\section{a. Market Penetration}

Microsoft's this strategy aims to see company's products present in every part of the global market. The company ensures market penetration by selling variety of products to the market where the company presently operates and introducing new products to prospective markets [13].

This approach is responsible for the worldwide dominance of the company's brand in the PC operating system industry. Effectively, the corporation ensures market presence by the generic approach which utilizes product distinctiveness to draw customers from different parts of the market.

\section{b. Product Development}

By innovation and up-gradation the company ensures new products are released and existing products are upgraded with modified and added features. This is how the company see that the products of Microsoft are relevant always in line with customers requirements. This is again in alignment with its generic strategy, which insists product distinctiveness as a competitive advantage [14].

\section{c. Market Development}

Market development signifies the expansion of company's market by entering into new \& emerging markets. Though this approach is not that significant to Microsoft on its current business performance as its products are already accepted globally and available everywhere, but through this approach the company expanded its markets at its early years.

\section{d. Diversification}

Product diversification is the key factor which helped Microsoft to register growth over the years. Introducing new products and upgrading existing products at regular intervals the company put its customers guessing. This is again in tandem with generic strategy "product differentiation" [15].

\section{FINANCE \& HUMAN RESOURCE :}

Microsoft Corporation's earnings rose 14 percent to \$125.84B for the fiscal year ended June 30, 2019. Net income rose 22 percent to $\$ 36.8 \mathrm{~B}$ before exceptional products. Revenues represent a rise in the 
segment of Intelligent Cloud from 21\% to \$38.99B, an increase in the segment of Productivity and Business Processes from $15 \%$ to $\$ 41.16 \mathrm{~B}$, and an increase in the segment of Personal Computing from $8 \%$ to $\$ 45.7 \mathrm{~B}$. As on June 30, 2019, Microsoft has 1,44,106 employees on roll worldwide, among them 1,37,160 are in USA and Puget Sound(Washington State). 45\% of employees under Engineering functions, $15.9 \%$ in Global Sales and Maintenance \& Operations, $17.9 \%$ in Worldwide Commercial Business, 10.2\% in LinkedIn, 6.1\% in Business Functions and 4.8\% in Finance, HR \& Legal [16]. The company's growth with respect to revenue \& income and human resource stock in the last 7 financial years is shown in the Table- 1 below.

Table 1 : Microsoft's financial and human resource account for last 5 years. (Period ending: 30/06)

\begin{tabular}{|c|r|r|r|r|}
\hline Year & $\begin{array}{c}\text { Revenue } \\
\text { (US\$M) }\end{array}$ & $\begin{array}{c}\text { Net income } \\
\text { US\$M) }\end{array}$ & $\begin{array}{c}\text { Total Assets } \\
\text { (US\$M) }\end{array}$ & Workforce \\
\hline 2019 & 125,843 & 39,240 & 286,556 & 144,106 \\
\hline 2018 & 110,360 & 16,571 & 258,848 & 131,000 \\
\hline 2017 & 96,571 & 25,489 & 250,312 & 124,000 \\
\hline 2016 & 91,154 & 20,539 & 193,468 & 114,000 \\
\hline 2015 & 93,580 & 12,193 & 174,472 & 118,000 \\
\hline
\end{tabular}

\section{MARKETING MIX :}

The marketing strategy exhibits how innovation powered by the efficient solution drives a company to maintain and sustain market share. It is based on 4Ps : Product-Place-Promotion-Price [17], which determines policies, strategy and tactics for a market-plan of a company. To safeguard digital products, Microsoft utilizes internet technology and technological interventions. The company is enjoying massive revenue as a significant player in the PC software and hardware industry. This market position is, however, threatened by competitive rivalry and linked problems. To guarantee ongoing achievement on the global market, the enterprise requires matching its marketing- mix with target market trends globally [18-19].

a) Products

Microsoft, since its inception, other than just software develop, has grown to include the diverse types of products such as 1) Devices, 2) Software, 3) Apps, 4) Games and 5) Entertainment. Surface lines of laptops, tablets Xbox and Windows Phone are the company's major products. Windows family operating systems, office suits server software, database tools, etc are its key software produces.

Its own free and proprietary tools offered by other companies are made available in Microsoft store ass Apps. Xbox games,

Windows games and other supportive tools are coming under the Games category of products. The movies and songs sold on the website of the company from which it receives percentage, which is treated as entertainment products [20].

b) Place/Distribution.

The company aims to reach a maximum number of people with its hardware and software products. In this marketing mix element, the company considered locations/[laces for interactivity with existing and potential customers. The company is using 1) Official Website, 2) Authorized sellers and 3) Microsoft Stores to market and distribute its products. Those who interested to review buy and download Microsoft products may do so by visiting the company's official website and stepping into the online store. Authorized Microsoft Product Sellers located at important commercial junctions across the globe provide company provision to reach its customers. In addition to these, the company's own physical Stores, provide an avenue to sell its customers directly to customers.

\section{c) Promotion}

Attract and reach new customers and retain existing ones are the focal points of Promotion. Considering computer software/hardware market conditions, the company's strategies and tactics are formalized and prioritized. They include 1) Advertising, 2) Sales Promotions, 3) Direct Marketing, 4) Personal Selling, and 5) Public Relations. The company considers Advertisement 
as the most significant way to reaching to customers so it spends most of its kept-aside promotion expenses on this. Discounts and product-specific incentives based on types of customers are its Sales Promotions. The company also conducts direct marketing with governments, establishments, organizations and academic institutions for sales. Sales personals at Microsoft Stores sell the product to customers. Though Microsoft Philanthropies, it promotes its products to a specific class of customers like the military.

\section{d) Price}

The other three elements of the marketing mix, that is, product, place, and promotion are directly dependent on this element. Appropriate and competitive pricing of products ensures its acceptance from the customers. For this, Microsoft adopted 1) Market-Oriented, 2) Freemium, and 3) Buy Only What You Use pricing strategies. Microsoft fixes prices of its very good number of products with relation to prevailing market indicators like competitiveness, consumer demand, and target market. It also uses Freemium-pricing where the product is offered to the customers free of cost and they need to pay for additional functionality/features. Moreover, the company also provides the 'buy-only-whatyou-use' pricing for its cloud-based products wherein the customer has to pay for only for those services he/she uses instead of fee for the entire device.

\section{MAJOR ACQUISITIONS :}

The generic strategy - 'Broad differentiation' and the thrust to expand the market lead Microsoft to acquire or merge number of start-ups, emerging or leading enterprises in its ambit. This helped the company to offer diversified products, command higher capitalization, enjoy market monopoly and put itself in competitive advantage. Starting from acquisition of Forethought Inc. in July 1987 to jClarity in Aug 2019, the company brought more than 250 establishments under its umbrella to date. That means, on an average, per year, the company acquired six companies. The most astonishing thing is that the company acquired ten companies by spending more than 1 billion dollar a peace. Table-2 highlights the company's major acquisitions as per the order of valuation [3].

Microsoft's saga of acquisitions began with the takeover of Forethought, the producer of presentation software in July 1987 for \$14 million. The product later became Microsoft PowerPoint. In June 1992, the Fox Software, the maker of database software was brought into the ambit of Microsoft. In December 1997, Hotmail.com was acquired by Microsoft for $\$ 500$, largest acquisition of the time, and its Web Mail Service was became the component of MSN services. Visio Corporation, the developer of diagram software was bought by Microsoft in January 2000 at the cost of $\$ 1.375$ billion. Navision, the developer of NAV ERP software was procured by Microsoft in July 2002 for \$1.33 billion. The product became the part of Microsoft Business Solution, which later nomenclature into Microsoft Dynamics. In August 2007, Microsoft acquired an advertising company aQuantive for $\$ 6.333$ billion and in the next year it made the Enterprise Search Company Fat Search \& Transfer its part for \$1191 billion.

Table 2 : Microsoft's Major Acquisitions.

\begin{tabular}{|l|l|c|r|}
\hline Rank & \multicolumn{1}{|c|}{ Company } & Acquisition Year & Valuation (\$M) \\
\hline 1 & LinkedIn & 2016 & 26,200 \\
\hline 2 & Skype & 2011 & 8,650 \\
\hline 3 & GitHub & 2019 & 7,500 \\
\hline 4 & Nokia (device unit) & 2014 & 7,200 \\
\hline 5 & aQuantive & 2007 & 6,333 \\
\hline 6 & Mojang & 2014 & 2,500 \\
\hline 7 & Visio Corporation & 1999 & 1,375 \\
\hline 8 & Navision & 2002 & 1,330 \\
\hline 9 & Yammer & 2012 & 1,200 \\
\hline 10 & Fast Search \& Transfer & 2008 & 1,191 \\
\hline
\end{tabular}


A tool for social networking, particularly for private business communication, Yammer was acquired by Microsoft in 2012 fo $\$ 1.2$ billion. In 2014, the mobile device unit of Nokia, the long-time partner of Microsoft was officially integrated with Microsoft for $\$ 1.7$ billion. It was later go the nomenclature Mobile Qy. Linkedin, the professional networking site was procured by Microsoft in 2016 for \$2.62 billion and a video game studio Mojang became part of Microsoft in 2017 for \$2.5 billion. In 2018, it acquired GitHub, a code repository for $\$ 7.5$ billion.

\section{MAJOR CUTBACKS :}

The first-ever biggest Microsoft's layoff was registered in July 2014, with the releasing of around $14 \%$ i.e. 18,000 employees from its regular roll. Earlier in 2009, the company cut-back its HR strength by 5,800 employees as pressured by the Great Recession of 2008-17. In Sept 2014, the company for the second time in a row released 2,100 employees from the registry. In June 2015, the company announced 7,800 layoffs. 1,850 personnel were putting an off-the-roll in May 2016, as the company restructured its cell phone division. The latest significant Microsoft layoff was recorded in 2018 with the cutback of employee strength by 4500 representatives from its finance section as the result of organizational restructuring [3].

\section{ORGANISATION STRUCTURE \& ITS ELEMENTS :}

Microsoft's organizational-structure enables the trade to fatten, particularly, after the revamp in structure introduced in 2015. The organizational structure of a company relates to the organization's anatomy and arrangement and its elements. The corporate organizational structure signifies the significance of company production in the case of Microsoft.

As an eminent player in the OS market, the corporation employs its organization-structure to keep competitive advantage in phase with development approaches. The long-standing success of the business relies on the appropriateness of its organizational structure to market circumstances and strengths of the segment.

The company is employing "product-type-division" structure. The essence of this type is the structural divisions based software \& hardware products. Following are the highlights of this type structure [21].

\section{Product Type Divisions}

Divisions based on product-type are the main element of the organization-structure of Microsoft. It utilizes product/production element as the significance criterion to group staff and element associated resources. This exhibits product innovation ability of the company in the organizational structure. As highlighted in Fig.-2, the product type divisions are - Productivity \& Business Processes, Intelligent Cloud, More Personal Computing and Corporate \& Other.

\begin{tabular}{|ll|}
\hline \multicolumn{1}{|c|}{ Product type divisions } & \multicolumn{1}{c|}{ Global corporate groups } \\
\hline - Productivity \& Business & $\circ$ Office of the CEO \\
Processes & $\circ$ Worldwide Commercial Business \\
$\circ$ Intelligent Cloud & $\circ$ Marketing \\
$\circ$ More Personal Computing & $\circ$ Global Sales, Marketing \& Operations \\
$\circ$ Corporate \& Other & $\circ$ Corporate Strategy and Operations \\
\hline Geographic segments & $\circ$ Cloud and Enterprise Group \\
\hline United States & $\circ$ Human Resources \\
$\circ$ International & $\circ$ Finance \\
& $\circ$ Business Development \\
& $\circ$ Applications and Services Group \\
& $\circ$ Windows and Devices Group \\
& $\circ$ Technology and Research \\
& $\circ$ Legal \\
\hline
\end{tabular}

Fig.-2 : Microsoft’s organizational structure and its elements 


\section{Global Corporate Groups}

The very organization-structure of Microsoft is defined by these groups. They are very crucial to company as technology based business totally relies on the task oriented components. The corporate groups are shown in Fig.-2, they are, United States and International.

\section{Geographic Segments}

The corporate structure of Microsoft Corporation also embodies geographic sections, which are made use to group operations in the company's fiscal statements. There are 13 geographic divisions, which are made known in Fig.-2. Office of the CEO, Marketing, Finance, Business Development, Cloud \& Enterprise Group, Applications \& Service Group, Technology \& Research, Windows \& Devices Group and Legal are a few examples.

\section{SWOC ANALYSIS :}

SWOC Analysis is an instrument used to determine organizational strengths and weaknesses (inner strategic factors) and company (external strategic factors) difficulties and possibilities. These variables underline the significance of Microsoft's situation of distinctive product development, cyber security, and company diversification. The business can attain continuing development in the market for computer hardware \& software through these methods. Figure Fig.3 highlights company's strength, weaknesses, challenges and opportunities [22].

\begin{tabular}{|l|l|}
\hline Strengths & Weaknesses \\
\hline - Dominant brand image & - Vulnerability to cybercrime \\
- Product alignment with & - Imitability of some products \\
positive externalities & - $\begin{array}{l}\text { Lack of dominant computer } \\
\text { hardware products }\end{array}$ \\
$\begin{array}{l}\text { Strong alliances with other } \\
\text { firms }\end{array}$ & Opportunities \\
\hline Challenges & - Business diversification \\
\hline - Cybercrime & - Innovation for computer \\
- Piracy & hardware products \\
- Strong competitive rivalry & - Stronger security against \\
& cybercrime \\
\hline
\end{tabular}

Fig.-3 : Microsoft's SWOC analysis outcomes

The brand 'Microsoft' is most familiar, trusted, reliable and the strongest one in the computer software-hardware spectrum. This image contributed a lot in attracting new brand enthusiastic customers and retail satisfied customers. Microsoft is the first choice for the brand viewers, who judge product by its brand image linked to reliability. Also, the company has been in understanding with major computer hardware manufacturers who integrate Microsoft products with their products. Thus, the brand image of Microsoft and alignment of products with market requirements put the company in competitive advantage.

Easy vulnerability of Microsoft products for cybercrime and threats has been considered as one of the most significant weaknesses of the Company. Its operating systems are always in danger of being easily attacked by the viruses and Trojan horses. Weaker security mechanisms of Microsoft products pose opportunities for the hackers to crack Microsoft products easily and infuse product piracy. Moreover, some of the Microsoft products fuse limited features compared to its competitors. Being long-time dominant software producer, Microsoft failed to embark the same image in the hardware filed. So, the company needs to enhance and streamline its security mechanisms and expand its hardware product lineups to be in competitive advantage.

Being the software giant, Microsoft mostly depends on its Windows family of operating systems for both growth and revenue. The company has a great opportunity to develop through product diversification. That is through acquiring more software-hardware manufacturing companies and diversifying its own products. So also, the company has visible opportunity in the area of computer hardware and emerging technology like IoT, Cyber Security and Artificial Intelligence. 
The main challenge to Microsoft is in the areas of cybercrime, piracy and competition from its rivals. Frequent attacks on Microsoft products in this Internet era jeopardize processes of its customer. The rampant piracy, especially in developing countries challenges the revenue expectation of the company. Moreover, the strong competition from its rivals poses a threat to the company.

To continue as one of the foremost players in the computer software \& hardware industry, Microsoft Corporation has the needed business characteristics. One of the main contributors to such a market condition is the powerful brand image and positive facade. Therefore, Microsoft is recommended to continue to enhance its brand image. It is also suggested to boost the company's collaboration with other enterprises in order to polish \& enhance positive facades.

\section{MAJOR COMPETITORS :}

Microsoft is a foremost performer in the computer software-hardware-IT services markets. The company is expanding its business in Media, Games, MSN TV, Mobile software \& hardware and Social Networks. Though the company is unparalleled in operating system market, it is facing hard competition in these areas of business. In Mobile Software, Media and IT services category, the company's product are under the pressure enforced by big players like Google, Apple, Amazon, and IBM. In social networking the company's presence is challenged by Facebook and Google+[23].

\begin{tabular}{|c|l|l|}
\hline Domain & \multicolumn{1}{|c|}{ Expansion } & \multicolumn{1}{c|}{ Main competitors } \\
\hline & - Media & - Mobile software \\
& - Games - Microsoft Studios, & Google (Android); Apple \\
& Xbox game console & (macOS, iOS); Apple-IBM \\
& - MSN TV & - Media \\
- Mobile soft-and hardware & Amazon, Google, Apple, \\
Computer Software & Skype, Bing, MSN, Surface & game developers \\
/IT services & (tablet), Windows Phone & - IT services \\
& - Social Networks & Google, Apple, Amazon, \\
& Linkedln & IBM \\
& & - Social networks \\
& & Facebook; Google+ \\
& & \\
\hline
\end{tabular}

Fig.4: Microsoft, areas of expansion and main competitors [16]

\section{STAKEHOLDERS :}

For Microsoft safeguarding the interest of its core stakeholders stands above to its own interest. The company identified, on priority basis, customers, employees, communities, investors and government as its prime stakeholders. It focuses on customer satisfaction \& customer retention with respect to customers, human rights, equal compensation, \& sophisticated work environment with regard to employees, environmental sustainability \& community-reach approaches in view of customers, maximum return, total transparency \& time-to-time reporting in case of investors and fall in-line with the prevailing legal \& regulatory procedures with respect to government. Figure Fig.5 showcasing key stakeholders of the company according to the priority anti-clockwise from customers to government [24].

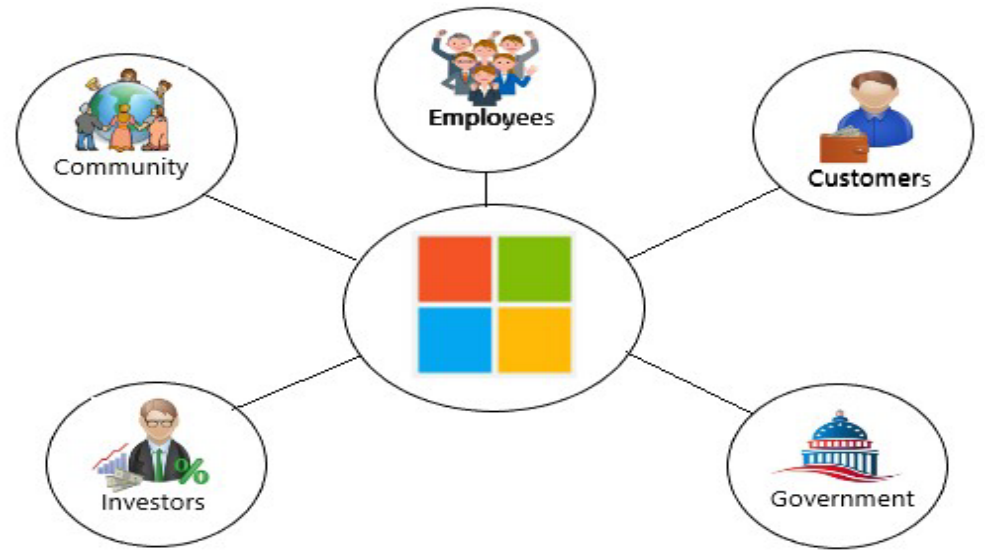

Fig 5 : Microsoft's stakeholders 
1. Customers (Top-Priority Stakeholders). For the sustained growth and long-time existence, Microsoft considered customer as its major stakeholder. The key interests of this group are diversified, fairly-priced, efficient \& user-friendly products and high quality after-sale service. In this regard the company striving hard to bring out variety of software and hardware products priced differently keeping in mind target customers and providing high-quality customer service through topnotch service centers penetrated across the world.

Furthermore, feedback systems allow the business to solve the complaints and problems experienced by clients when using the products of company. Microsoft provides some client specific discounts targeting specific interest groups to further the thrust.

2. Employees. Microsoft considers human resources, that is, workforce is the second most significant stakeholders. It views human rights, industry-standard compensation package, congenial work atmosphere and respectful treatment of staff as the interests of this group. The involvement of this group directly influences the production and performance of the Company. To fulfill the interests of staff, the corporate take care of competitive reward and continuous improvement in employment procedures to safeguard the freedoms of workers. These in turn promote the enhancement of human resources while improving workers' morale and skills.

3. Communities. Microsoft considers communities as one of the most precious stakeholders as its product and services, both software and hardware oriented are made for the direct use by the public. Taking care of this group's interest directly benefit Microsoft to enhance business and maintain prevent brand-image. To address this, the company included number of provisions in its market issues like discounts for students, defense staff and ex-servicemen.

Also, Microsoft Philanthropies donate fund and extend aid to wide range of CSR programs. Such initiatives improve the accessibility of a large group of users to company's products. Moreover its policy on environmental sustainability reflects Microsoft's commitment to minimize its environmental effect.

4. Investors. Microsoft considered investors in its software-hardware business as another significant stakeholder. Investor supply capital to the Company. Sustained business growth and accurate \& transparent fiscal reporting are the key interests of this stakeholder. The corporate responsibility attempts of Microsoft meet interests of this group through a multitude of company. The company's business-stability also addresses investors interest furthering the development of the corporation.

5. Governments. For Microsoft, government is un-separable stakeholder as rules \& regulations and policies of the states directly affect the functioning of the company. In the compliance of legal and regulatory procedures of Microsoft, the involvement of government is desirous, so also in the contribution of economic growth. Microsoft fulfills the interests of this group through the organization's strict policies.

\section{CONCLUSION :}

Microsoft Corporation, being a technology company that deals with producing and selling of computer software, hardware and services across world, has been rising significantly since its inception. The company has registered growth in its revenue over the years from $\$ 16,000$ in 1975 to $\$ 125,843$ million in 2019. Began with just 3, including the founders, the company has 144,106 employees on a roll today [2]. Microsoft products are ubiquitous today. The company has in its control \$286.556 million assets spread across the world. As of June 30, 2019, more than 800 million devices are loaded with Windows 10. The company has already analyzed more than 6500 billion messages to find out threat issues and by that protecting its valued customers. 18 billion questions has already been asked to Cortana, intelligent Assistant of Microsoft since its launch. These facts emphasize the popularity of the company [25]. Microsoft continues to grow as a technology giant confronting and overcoming all odds. In line with its 'Be What's Next' tagline, the business has so far succeeded in guessing its customers

\section{REFERENCES :}

[1] Microsoft Annual Report 2018. Retrieved from https://www.microsoft.com/en-us/ annualreports/ ar2018/annualreport on 10/08/2019. 
[2] Microsoft by the Numbers. Retrieved from https://news.microsoft.com/ythenumbers/ en/homepage on 10/08/2019.

[3] Microsoft - Wikipedia (2019), Wikipedia. Retrieved from https://en.wikipedia.org/ wiki/Microsoft on 10/08/2019.

[4] Aithal, P. (2017). Company Analysis - The Beginning Step for Scholarly. International Journal of Case Studies in Business, 1(1), 1-18. DOI: https://doi.org/10.5281/zenodo.573769

[5] Aithal, P. (2017). Industry Analysis-The First Step in Business Management Scholarly Research. International Journal of Case Studies in Business, 1(2), 1-13. https://doi.org/10.5281/zenodo.810347.

[6] Zaidah, Z., \& Zainal, Z. (2007). Case study as a research method. Jurnal Kemanusiaan, 9(Journal Article), 1-6. https://doi.org/10.1177/15222302004003007

[7] Gregory, Lawrence. "Microsoft's Mission Statement \& Vision Statement (An Analysis)." Panmore Institute( 2019). Retrieved from http://panmore.com/microsoft-corporation-visionstatement- mission-statement-analysis on 10/08/2019.

[8] Crobat. Microsoft Company(1975). Retrieved from https://www.thocp.net/companies/ microsoft/ Microsoft company.htm on 10/08/2019.

[9] Hall, M., \& Zachary, G. P.. Microsoft Corporation. Retrieved from https://www.britannica. com/topic/Microsoft-Corporation on 10/08/2019

[10] Lawrence Gregory (2017), Microsoft Corporation's Generic \& Intensive Growth Strategies. Retrieved from http://panmore.com/microsoft-corporation-generic-strategy-intensive-growthstrategies on $10 / 08 / 2019$.

[11] Essays, UK. (2018). Microsoft's success: Corporate strategy and human resources strategy. Retrieved from https://www.ukessays.com/essays/business/microsofts-success-in-aligningcorporate-strategy-and-human-resources-strategy-business-essay.php?vref=1 on 10/08/2019

[12] Noor, K. B. M. (2008). Case study: A strategic research methodology. American Journal of Applied Sciences, 5(11), 1602-1604. https://doi.org/10.3844/ajassp.2008.1602.1604

[13] R, C., P, K., \& P, P. (2015). Business groups in developing capital markets: Towards a complementarity perspective. Strategic Management Journal, 127(1), 12-13. DOI: https://doi.org/10.1002/smj

[14] Hitt, M. A., Hoskisson, R. E., \& Kim, H. (1997). International diversification: Effects on innovation and firm performance in product-diversified firms. Academy of Management Journal, 40(4), 767-798.DOI: https://doi.org/10.2307/256948

[15] Chang, S. C., \& Wang, C. F. (2007). The effect of product diversification strategies on the relationship between international diversification and firm performance. Journal of World Business, 42(1), 61-79. DOI: https://doi.org/10.1016/j.jwb.2006.11.002

[16] Microsoft (MSFT) Financial Summary. Retrieved from https://in.investing.com/equities/ microsoft-corp- financial-summary on 10/08/2019.

[17] Smithson, N. (2017). Microsoft Corporation's Marketing Mix (4Ps) Analysis. Retrieved from http://panmore.com/microsoft-corporation-marketing-mix-4ps-analysis on 10/08/2019

[18] Kretschmer, K., \& Meyer, D. S. (2007). Platform Leadership. American Behavioral Scientist, 50(10), 1395-1412. DOI: https://doi.org/10.1177/0002764207300163

[19] Klein, B. (2001). The microsoft case: What can a dominant firm do to defend its market position? Journal of Economic Perspectives, 15(2), 45-62. DOI:

htts://doi.org/10.1257/jep.15.2.45 
[20] Lee, S. Y. T. (2000). Bundling strategy in base-supplemental goods markets: The case of microsoft. European Journal of Information Systems, 9(4), 217-225. DOI: https://doi.org/10.1057/palgrave.ejis.3000377

[21] Jessica Lombardo (2018), Microsoft Corporation's Organizational Structure \& Its Characteristics (An Analysis). Retrieved from http://panmore.com/ microsoft-corporationorganizational-structure-characteristics-analysis on 10/08/2019.

[22] Edward Ferguson (2017), Microsoft Corporation's SWOT Analysis \& Recommendations. Retrieved from http://panmore.com/microsoft-corporation-swot-analysis-recommendations on 10/08/2019 on 10/08/2019.

[23] Zhou, Youyou. "Thirty Years of Financial Filings Reveal Microsoft's Biggest Competitors.” Quartz, Quartz(2019). Retrieved from https://qz.com/1553700/this-30-yeartimeline-reveals-microsofts-biggest-competitors/ on 10/08/2019.

[24] Lawrence Gregory, (2017), Microsoft's Corporate Social Responsibility Strategy \& Stakeholders (An Analysis). Retrieved from http://panmore.com/ microsoft-stakeholderscorporate-social-responsibility-strategy-analysis on 10/08/2019.

[25] Facts About Microsoft. Retrieved from https://news.microsoft.com/ facts-about-microsoft/ on 10/08/2019. 